\section{Australian Water Supply}

ThE water supplies of certain parts of Australia, and the occurrenee of periodic drought, are the subject of comment by Dr. J. P. Thomson in an article in the Sydney Morning Herald of January 12. As a result of observations ranging over half a century, Dr. Thomson believes that there are unmistakable signs of desiccation and he advocates the immediate necessity of measures to preserve the water supplies and to resist the ill-effect of droughts. He points to observations on Lake George and various lagoons in the eastern part of New South Wales as well as Lake Eyre as showing rapid deterioration in humidity. The wells of the great artesian basin, according to him, are showing signs of decreased flow which he attributes to the plutonic and therefore limited supply of the water. He points also to the decreased flow in many water courses and the serious loss of water by excessive evaporation in the dry atmosphere. Dr. Thomson would like to see every effort to conserve water by preventing waste of flood water and checking the number of wells, and he favours also the preservation of fodder against times of stress. $\mathrm{He}$ points also to the urgent need of better weather forecasts, which he thinks must come from the antarctic, in order to give the farmer warning of any surplus or deficiency in rainfall. Measures such as these might go hand in hand with more land settlement and production for wider markets.

\section{Russian Arctic Expeditions}

IN recent years the Soviet Union has paid a great deal of attention to the exploration of its arctic territories and the investigation of commercial sea routes north of Siberia. The Society for Cultural Relations between the Peoples of the British Commonwealth and the U.S.S.R. has recently directed attention to the activities of Soviet arctic expeditions in 1932. Most important were the establishment of observatories at Cape Chelyuskin, at Rudolph Island in Franz Josef Land, in Novaya Zemlya and at the mouth of the Lena River. The Rudolph Island station is to be the base of a thorough exploration of Franz Josef Land and the little-known seas to the east. Several ice-breakers were engaged in hydrographical work in the Barents and Kara Seas while the Sibiriak, which made the north-east passage from Archangel to Bering Strait, reports that ice congestion in the western part of the passage can be avoided by passing north of Northern Land. It is by no means certain, however, that this route could be relied on every year in maintaining communication between White Sea ports and the Lena River, though the possibility is worth investigating.

\section{Annales Guebhard-Séverine}

WE have received No. 8 of these annals, which have been issued yearly since 1925 by the Institut Guebhard-Séverine, 4 Rue du Seyon, Neuchâtel, Switzerland, and are distributed free on application to the Institut, to investigators in all countries. The Institut is also willing to publish scientific works written in any of the languages French, English,
German or Italian; its practice appears to be to translate into French for publication. Papers on subjects studied by the late Adrien Guébhard are particularly invited; these subjects include geophysics and geology, botany, electricity, hydrodynamics, osmosis, biological physics, meteorology, acoustics, photography and spectroscopy. The present number of the annals contains four papers, by $R$. Reinicke on the tetrahedral field of action of atoms, by $\mathrm{F}$. Strunz on the natural sciences in the work of Albertus Magnus, by L. Courvoisier on researehes to determine the 'absolute' motion of the earth, and by D. Chahnazaroff on petroliferous waters.

\section{Institute of Physics}

THE recently issued annual report for 1932 of the Board of the Institute of Physics shows a satisfactory record of work during the year. There has been a steady increase in membership of the Institute which now has about seven hundred names on its roll. The local sections, too, in Australia and India, report a successful year. During the year, a local section was formed at Manchester under the chairmanship of Prof. W. L. Bragg with Dr. H. Lowery of the Physics Department of the University as local secretary. The following officers among others have been elected for the session 1933-34: President, Sir Henry Lyons ; Treasurer, Major C. E. S. Phillips ; Secretary, Prof. J. A. Crowther.

\section{Third International Congress of Experimental Cytology}

THE third International Congress of Experimental Cytology will be held at Cambridge on August 21-26. The international president is Prof. Th. Huzella, professor of anatomy in the University of Debrecen, whose presidential address will be entitled "Culture des tissus en ses relations aux problèmes générales de la biologie et aux problèmes speciales de la médecine". The chief feature of the Congress will be discussions on the following topics: "Cell Respiration and Cell Metabolism" ; "Cell Form and Function as demonstrated by Recent Advances in Tissuo Culture"; "The Electro-Physiology of the Cell"; "Entwicklungsmechanik und Explantation"; "The Cultivation of Animal and Plant Viruses". Papers will be presented by authors from Great Britain, Germany, Austria, Hungary, U.S.S.R., United States, Poland, Italy, Holland, Czechoslovakia, France, Switzerland, Denmark, and Japan. Among the distinguished foreign visitors will be Prof. H. Wieland (Munich), Prof. A. Szent-Györgyi (Budapest), Prof. R. Chambers (New York), Prof. W. J. V. Osterhout (New York), Prof. J. Michaelis (New York), Prof. S. C. Brooks (Berkeley), and Dr. K. Landsteiner (New York). Further information concerning the Congress can be obtained from Dr. Honor B. Fell, Strangeways Research Laboratory, via Cherryhinton, Cambridge.

\section{Twenty-fifth Anniversary of the French Society of Physical} Chemistry

A programme has now been arranged for the meetings which are to celebrate the twenty-fifth anniversary of the French Society of Physical 
Chemistry, to which reference has already been made in these columns (Jan. 14, p. 53). Two general discussions will be held on Oct. 16-22, on "The Electron Theory of Metals" and on "Electrolytes and Boundary Layers (Electrode-Solution)". Among those who have already promised contributions to the discussions are Prof. Brillouin (Paris), F. Bloch (Leipzig), Prof. V. Henri (Liège), Prof. Joffé (Leningrad), Prof. E. K. Rideal (Cambridge), Prof. M. Volmer (Berlin), Prof. P. Debye (Leipzig), Prof. P. Dutoit (Lausanne), R. Audubert (Paris), Prof. F. Dubois (Clermont-Ferrand), A. H. Wilson (Cambridge), Prof. A. Gillet (Liège), Prof. O. Scarpa (Milan), Prof. Denina (Turin), Prof. J. Heyrovský (Prague). Notification of proposed attendance at the meeting should be sent as early as possible to the General Secretary of the Society, Dr. Ch. Marie, 9 rue de Bagneux, Paris (VI). The registration fee is 125 francs, including reception, banquet, excursions, etc., as well as advance copies of papers for discussion. Advance proofs will be forwarded immediately to those who pay their registration fee before June 30 ; others will receive them at the meeting in October.

\section{Sixth Imperial Social Hygiene Congress}

The sixth Imperial Social Hygiene Congress will be held at the London School of Hygiene and Tropical Medicine, Keppel Street, London, W.C.1 on July 3-7 under the presidency of Sir Basil Blackett. On July 3 , the presidential address will be delivered, and the rest of the Congress will be divided into a series of discussions including such topics as the effect on established social customs of modern knowledge and economic conditions; changes in the outlook on prostitution; biology and health - the teaching of biology in schools and colleges ; conference of teachers of biology ; methods of dealing with venereal disease in the defence forces of different nations; the training, etc., of health visitors, nurses and midwives; venereal disease administration and the supply of educational and cultural films. Progress reports from Great Britain and the Dominions concerning different branches of social hygiene will be presented at the Congress. Arrangements have been made for visits to various institutions of interest to the delegates, a special display of films, and an exhibition of simple equipment used in biological teaching. Further information concerning the Congress can be obtained from the Secretary, British Social Hygiene Council, Carteret House, Carteret Street, London, S.W.1.

\section{Announcements}

Aт a meeting of the Royal Society held on May 25, the following were elected foreign members of the Society : Prof. Vilhelm Friman Koron Bjerknes, of the Physical Institute of the University of Oslo; Prof. Harvey Williams Cushing, of New York, distinguished for his work on the surgery of the brain; Prof. Peter Debye, professor of physics in the University of Leipzig; Prof. Friedrich August Ferdinand Christian Went, professor of general botany in the University of Utrecht.
THE annual visitation of the National Physical Laboratory will take place on June 27 from 3 to 6 p.m.

The Right Hon. Lord MrLchetr has consented to accept the presidency of the British Science Guild in succession to the Right Hon. Sir Samuel Hoare, whose three-year term of office ends this month. Lord Melchett will be elected president of the Guild at the annual general meeting to be held in the Mansion House on June 19 at 4.30 p.m. when the Right Hon. The Lord Mayor of London (Sir Percy W. Greenaway) has kindly agreed to take the chair.

AT the anniversary meeting of the Linnean Society of London held on May 24 the following were elected officers of the Society:-President, Prof. F. E. Weiss; Treasurer, Mr. Francis Druce; Botanical Secretary, Mr. John Ramabbottom; Zoological Secretary, Dr. Stanley W. Kemp.

THE annual general meeting of the British Science Guild will be held in the Mansion House, London, E.C.4, on June 19, at 4.30 p.m., when the chair will be taken by the Right Hon. the Lord Mayor of London. The meeting will be followed by a popular lecture entitled, "Some Problems of British Forestry", by Prof. R. S. Troup, professor of forestry in the University of Oxford and director of the Imperial Forestry Institute.

Appuicatrons are invited for the following appointments on or before the dates mentioned :-An assistant lecturer in mathematics at the University College of South Wales and Monmouthshire-The Registrar, University College, Cardiff (June 12). A director of research at the Forest Products Research Laboratory, Princes Risborough-The Secretary, Department of Scientific and Industrial Research, 16, Old Queen Street, Westminster, S.W.1 (June 22). A lecturer in pathology at the University of LiverpoolThe Registrar (June 24). A head of the Manual Training and Engineering Department of Christ's Hospital, Horsham-The Headmaster. An assistant lecturer in agricultural botany at the University of Reading-The Registrar. A part-time teacher of bakery science (especially elementary physics and chemistry) at the Borough Polytechnic, London, S.E.1-The Principal. A head of the Mining Department at the County Technical College, Mansfield-The Principal. A lecturer in biology and some mathematics at the Stockwell Training College, London, S.W.9-The Principal. External examiners in scientific, medical and other subjects for various degree examinations in the University of LondonThe External Registrar, University of London, South Kensington, S.W.7 (July 3).

Erratum.-In Nature of May 27, p. 764, twelve lines from foot of first column, for " $n n$ higher unstable and lower grades" read "unstable $n n$ higher and lower grades". 